\title{
ANMELDELSER
}

\section{Fanny Ambjörnsson: I en klass för sig. Genus, klass och sexualitet bland gymnasietjejer. Stockholm: Ordfront 2003. 304 sider. ISBN 91-7037-027-3 (pb). Pris: 269 SVK.}

Fanny Ambjörnsson, som er kendt fra den svenske debat om unge kvinders nutidige liv, er uddannet socialantropolog. Sammen med fire venner har hun skrevet bøgerne Ett hjärta i jeans. Och andra texter om tjejer och tjejers grejer (Alfabeta 1997) og Uppror pågår. Feminister i tre generationer (Alfabeta 1999), som henvender sig til unge i blandt andet gymnasiet, ligesom hun har bidraget til forskellige antologier. Den førstnævnte bog bygger på interviews, samtaler og skønlitterære tekster om, hvordan det er at vokse op som ung kvinde i dagens Sverige. Det fremgår ikke af I en klass för sig, om det er via dette arbejde og formidlingen heraf på fx ungdomsuddannelsesinstitutioner, at Ambjörnsson er blevet inspireret til at udforske mere dybtgående, hvordan man bliver ung kvinde i Sverige. Det er imidlertid dét spørgsmål, der står i centrum i bogen, som er hendes doktorafhandling udi antropologi. Ambjörnssons projekt har været del af et større forskningsprojekt „Heteronormativitet“, der var ledet af den amerikansk-svenske antropolog Don Kulick, der blandt andet har skrevet om temaer såsom køn og seksualitet.

Bogen lever op til en afhandlings form og krav, samtidig med at den - skønt der anvendes fagsprog - kan læses af et bredt publikum med et vist uddannelsesniveau. Den er yderst velstruktureret og velskrevet, ligesom fremstillingsformen er vældig levende med glimrende anvendelse af det empiriske materiale. Den gåde, som Ambjörnsson analyserer, er, hvordan man bliver ung kvinde i dagens Sverige. Hvilke idealer, normer og krav må man forholde sig til? Hvad består normalitet i? Hvordan skabes, opretholdes, problematiseres og forhandles normalitet unge kvinder imellem? Og hvad sker der, når man ikke lever op til normaliteten? Der er således fokus på normalitet og afvigelse, opvækst og sociale vilkår i forhold til femininitet - i et skæringspunkt mellem social klasse og seksualitet. Formålet med bogen er - med udgangspunkt $\mathrm{i}$ to grupper af teenagepiger med forskellig klassebaggrund - at undersøge, hvordan feminine kønspositioner skabes inden for rammerne af et heteronormativt system.

I det første kapitel præsenteres hovedbegreber (køn, femininitet, heteronormativitet, normalitet) og de processer, der sættes fokus på, nemlig sammenvævning af kategorierne køn, seksualitet, klasse og etnicitet i konstruktionen af femininitet og normalitet, ligesom 
der kort introduceres til eksisterende ungdomskulturforskning og forskning i unge kvinder. Endvidere præsenteres den teoretiske ramme for projektet, som primært består af den amerikanske feministiske filosof Judith Butler - og mere bredt den såkaldte ,,queer-forskning", som sætter heteronormativitet under lup. Endvidere er den engelske sociolog Beverly Skeggs teoriapparat en stor inspirationskilde, idet hun ser på syntesen mellem klasse og køn og på vigtigheden af at opnå respektabilitet. Også Pierre Bourdieus begreber om de forskellige kapitalformer samt hans analyser af distinktioner og smag samt Michel Foucaults magtbegreb udgør vigtige teoretiske afsæt. Endelig er der oplysninger om de anvendte metoder, hvilket empirisk materiale undersøgelsen bygger på samt metodiske refleksioner ( $\mathrm{fx}$ forskeren $\mathrm{i}$ felten). Introduktionen afrundes med en præsentation af bogens kapitler.

Bogen omhandler unge kvinder (som på svensk betegnes ,tjejer“ og ikke „flickor“) på et gymnasium i en forstad til Stockholm. Ambjörnsson fulgte løbende de unge i et års tid, dvs. at hun bedrev etnografisk feltarbejde, der indebar forskellige metoder, og som førte til forskelligt empirisk materiale: deltagerobservation (feltnoter fra lektioner og samvær med de unge på skolen plus et vist samvær uden for skolen), enkelt- og gruppeinterview med de unge kvinder (interviewtekster), uformelle samtaler med lærere og rektor (feltnoter) samt en spørgeskemaundersøgelse henvendt til alle i de to klasser, hun fulgte. Forfatteren inddrager på kreativ vis fiktionsfilm som fx den succesrige ungdomsfilm Fucking Åmål såvel som andre forskeres undersøgelser af pigeblade og nutidige tv-programmer, film og blade, som de unge kvinder refererer til, og/eller som forfatteren anvender til at diskutere sin empiri i forhold til.

Gymnasiet i Sverige er indrettet på en anden måde end i Danmark. I Sverige er der flere „gymnasieprogrammer" på samme skole, og Ambjörnsson fulgte henholdsvis et studieforberedende og et erhvervsforberedende program. Herved fik hun belyst klassemæssige forskelle, idet der var klare socioøkonomiske forskelle mellem eleverne (og i forældregruppernes uddannelsesniveau og erhvervsmæssige status) i de to programmer. Da en del af eleverne, herunder de unge kvinder, som hun fokuserer på, var etniske minoriteter af varierende herkomst, beskæftiger hun sig også med forskelle og ligheder mellem etnisk svenske pigers og etniske minoritetspigers opfattelser af og forholden sig til femininitet, seksualitet og normalitet. I kapitel to præsenteres de to pigegrupper, som indgår i bogen. Ved at diskutere, hvordan disse på forskellig vis forholder sig til en normativ femininitet, viser Ambjörnsson, hvordan de processer, hvori der skabes køn, må forstås i relation til de to gruppers/den enkelte unges forskellige klassetilhørsforhold.

Kapitel tre handler om, hvordan den normative femininitet er utvetydigt heteroseksuel. Her undersøges, hvilke bestanddele der indgår i det heteronormative system, hvilke relationer og handlinger der kræves af den enkelte unge kvinde, for at hun kan blive betragtet som normal. Den normative heteroseksualitet står i fokus i kapitel fire, hvor forfatteren diskuterer, hvordan kroppen er central både som symbol på og som redskab i skabelsen af heteroseksuelle personer. Med udgangspunkt i forskellige forvandlingsakter på kroppen (såsom at barbere hår væk bestemte steder på kroppen og/eller at klæde sig på bestemte måder) diskuterer Ambjörnsson, hvordan den normative femininitet fremstår som ensbetydende med en bestemt slags kvindekrop. Hvordan man ,gør“ den feminine krop, synes også centralt for de unge kvinders selvopfattelse og opfattelse af hinanden som „normale piger".

I de følgende tre kapitler undersøges de positioner, der skabes som afvigende og ikkeønskværdige: Kapitel fem behandler fænomenet „luderen“. Med udgangspunkt i situationer 
og historier, hvor betegnelsen ,luder“ har været virksom, diskuteres den ambivalens, som giver begrebet dets kraft. Endvidere beskriver forfatteren, hvordan begrebet „luder“ gennemsyres ikke blot af et kønssystem, men også af klasse- og etnicitetsstrukturer. Kapitel seks handler om lesbiskhed - både som stereotyp og som en mulig position, man kan indtage. Med udgangspunkt i de unges forestillinger og tale om homoseksualitet diskuteres de subtile måder, hvorpå kvindelig seksuel afvigelse både affærdiges og usynliggøres. Samtidig vises, hvordan kvindelig homoseksualitet konstrueres i relation til den heteroseksuelle femininitet, der fremstår som normal. Fokus i kapitel syv er, hvordan normalitet fremmanes som svensk og hvid. Ud fra de unge kvinders forestillinger om og relationer til såvel unge mænd som unge kvinder af udenlandsk herkomst undersøges de processer, gennem hvilke den frie, selvstændige og respektable unge kvinde konstrueres som svensk. At det er en fri og selvstændig ung kvinde, som synes at udgøre et ideal, tages op i kapitel otte. Ved at undersøge, hvordan de unge kvinders mundtlige selvfremstilling kredser omkring vigtigheden af at fremstå som frie individer, belyser Ambjörnsson, hvordan den attråværdige individualitet synes lettest opnåelig gennem en kropsliggørelse af normen. Herved illustreres, at den umiddelbart neutrale opfordring til at ,,være sig selv“ er lettere at virkeliggøre for nogle af de unge kvinder end for andre.

Kapitel ni er en sammenfatning af undersøgelsens hovedpointer og væsentligste bidrag. Forfatteren tager udgangspunkt i spørgsmålet om, hvorvidt de unge kvinder kan betragtes som undertrykte, og diskuterer, hvordan et fokus på skæringspunktet mellem forskellige stratificeringsprincipper bidrager til at nuancere og komplicere fænomener som magt, modstand, underordning og undertrykkelse.

Bogen er karakteriseret ved et meget fint analytisk blik, interessant empirisk materiale om unge kvinder, som udnyttes optimalt, spændende analyser og en levende fremstilling. Det lykkes for forfatteren at fremstille såvel teoretiske som komplicerede empiriske problemstillinger på en sådan måde, at det ikke føles vanskeligt at læse og at følge argumentationen. Læseren kan mærke den teoretiske tæthed, der ligger i analyserne, men den virker ikke tyngende, dvs. der er en „tyk beskrivelse“ på spil. Bogen indskriver sig i en nordisk og britisk ungdomsforskningstradition, samtidig med at den er et forfriskende nyt bidrag på flere måder: 1) Der eksisterer ikke megen forskning hverken i Norden eller i Danmark om unge på ungdomsuddannelsesinstitutioner - og slet ikke undersøgelser, der har benyttet sig af etnografiske metoder. 2) Der er mangel på viden om unge kvinder og skabelsen af femininitet og seksuel normativitet i det senmoderne Norden, så bogen bidrager til at udfylde dette videnshul. 3) Bogen indskriver sig i og operationaliserer den såkaldte ,,intersektionalitetstilgang“, dvs. en tilgang, der analyserer flere sammenvævede ulighedssystemer på en gang - her køn, seksualitet, klasse og etnicitet. Såvel bogens tematikker som dens teoretiske og analytiske tilgang er således yderst aktuelle.

Yvonne Mørck Lektor

Institut for Samfundsvidenskab \& Erhvervsøkonomi Roskilde Universitetscenter 